\title{
Article \\ Detection of heavy metals in poultry feed, meat and eggs
}

\author{
M. A. Rashid ${ }^{1 *}$, M.S.K. Sarker ${ }^{1}$, H. Khatun ${ }^{1}$, N. R. Sarker ${ }^{2}$, Md. Yousuf Ali $^{1}$ and M.N. Islam ${ }^{3}$ \\ ${ }^{1}$ Poultry Production Research Division, Bangladesh Livestock Research Institute, Savar, Dhaka-1341, \\ Bangladesh \\ ${ }^{2}$ Animal Production Research Division, Bangladesh Livestock Research Institute, Savar, Dhaka-1341, \\ Bangladesh \\ ${ }^{3}$ Ex-Director General, Bangladesh Livestock Research Institute, Savar, Dhaka-1341, Bangladesh
}

*Corresponding author: M. A. Rashid, Bangladesh Livestock Research Institute, Savar, Dhaka-1341, Bangladesh. E-mail: marashid31@yahoo.com

Received: 28 December 2017/Accepted: 15 May 2018/ Published: 31 May 2018

\begin{abstract}
The poultry feed, meat and egg samples were collected from the major poultry raising areas of the country to know the presence of heavy metals especially arsenic (As), lead ( $\mathrm{Pb}$ ) and chromium ( $\mathrm{Cr})$. A total of 360 elemental samples for $\mathrm{As}, \mathrm{Pb}$ and $\mathrm{Cr}$ were analyzed in the laboratory. The heavy metal contents $\mathrm{As}, \mathrm{Pb} \&$ $\mathrm{Cr}$ ) of all the tested samples were found positive. But, the levels were below the Maximum Permitted Concentration (MPC) in most cases. The layer and broiler ready feed samples found safe from those elements; On the other hand, the "Cr" and "Pb" content in $14 \%$ and $11 \%$ loose feed samples were 7-70 and 3 times respectively higher than that of MPC. Notes worthy, the egg samples were also found safe from those elements. Of the tested samples $14 \%$ broiler meat and $50 \%$ spent hen samples found slightly higher level of "As" and 4-6 times "Cr" respectively than the MPC. In conclusion, the poultry farmers are suggested to buy poultry feeds from the reputed feed company and discourage to use loose feeds. Moreover, feed marketing channel particularly loose feed marketing should be monitored properly by the regulatory authority.
\end{abstract}

Keywords: heavy metals; poultry; feed; meat; egg

\section{Introduction}

Food safety has become an integral part of the relevant production processes to meet the strongly negative reactions of consumers and consumer's organizations to recent crises in the food- animal industry (Mulder, 2011). He also mentioned that truly safety products are free from microorganisms that are pathogenic to man and without any residues of substances used in primary production, including antibiotics and other chemicals, or foreign bodies. Livestock and poultry origin food viz. meat, milk. egg etc. one of the sources of both chemical and microbiological hazard, may play an important role in the transmission of drug residues and disease producing microorganism (Hillerton et al., 1999). Sarker et al. (2011) mentioned that inappropriate use of antibiotics or other foreign substances is undesirable for residues which may produce toxic or allergic reactions in susceptible individuals who eat meat or egg that contains residues. Metals such as $\mathrm{Fe}, \mathrm{Cu}, \mathrm{Mg}, \mathrm{Co}, \mathrm{Zn}$ are essential for human body but chronic metabolic disturbances may occur due to the deficiency or excess of these metals. Non essential elements such as $\mathrm{Pb}, \mathrm{Cd}, \mathrm{Cr}, \mathrm{Ni}$ and $\mathrm{As}$ are considered to be toxic and their presence in the body can cause profound biochemical and neurological changes in the body. For the sake of safeguard human health, the World Health Organization (WHO) and Food and Agriculture Organization (FAO) have set standards for acceptable daily intake and maximum residue limits in foods inter alia.

These limits apply to both the parent drug or chemical and its metabolites that may accumulate and be deposited or stored within the cells, tissues or organs following the administration of the compound (Jenseen, 1980). Due to various consequences the contaminants may enter in to the food chain. Since the poultry products (egg and meat) comparatively cheaper and easily available; therefore, a wide range of consumers intake the poultry 
products. On the other hand, to make a brisk business some unscrupulous businessmen often add the toxic tannery waste in poultry feeds as protein source, through which the toxic component may transfer into the poultry meat and eggs. Vasanthakumar et al., 2013 conducted a study in Namakkal area of Tamil Nadu, India and reported that the animal protein sources such as fish meal, meat meal, meat and bone meal sold in the market are mostly adulterated with leather meal. Recently, heavy metal poisoning in human through poultry products has been earning due attention by the experts; especially for arsenic, lead and chromium. However, literatures' regarding the study of heavy metals in eggs and meat is scant. Therefore, as food safety issues, it is essential to know the extend of heavy metal presence in poultry feeds, meat and eggs. With those ideas in mind, the present study was aimed to investigate the levels of heavy metals $(\mathrm{As}, \mathrm{Pb} \& \mathrm{Cr}$ ) in poultry feed, meat and eggs in comparison to the recommended level for safe human health.

\section{Materials and Methods}

In order to get real scenario about the presence of heavy metals content in poultry feeds, meat and eggs; samples were collected from major poultry rearing areas of the country e.g. Dhaka (Savar, Dhamrai, Gazipur), Chittagong and Sorupkati, Pirojpur. Other than these areas, samples were collected from Narsingdi, Narayanganj, Dinajpur, Sherpur, Jamalpur, and Bogra. In addition, some market samples from Savar, Nabinagar and Nimtoli, Dhaka were also collected. To collect the representative sample both from the branded ready feed and locally made loose feed, the farm and market samples, and the urban and peri-urban samples were also collected. In most cases, feed samples were collected along with the eggs and/or meat samples from the same farm. A total of 360 samples for As, Pd and Cr were analyzed from 120 different poultry feed, meat and egg samples. To determine the presence of heavy metals in eggs, the egg samples were boiled and oven dried the yolk and albumen separately for 72 hours with $75-80^{\circ} \mathrm{C}$ temperature and then make it powder using grinder machine. Meat samples were collected from breast, thigh and drumstick parts of the body then minced by mincing machine and oven dried similar ways done for egg samples and finally made powder by grinder. Feed samples collected from the fields were packed properly giving individual code number and send to laboratory for analysis. Then, 0.5 gram of sample was weighed and transferred to $100 \mathrm{ml}$ of glass beaker. Then $5 \mathrm{ml}$ of pure $\mathrm{HNO} 3$ and $1 \mathrm{ml}$ of $\mathrm{HClO} 4$ were added and allowed for over night, then the beaker was placed on hot plate to raise its temperature up to $140-180{ }^{\circ} \mathrm{C}$ until the sample completely digested with reducing of its volume to 1 - $3 \mathrm{ml}$. Then added 1-2 $\mathrm{ml} \mathrm{H}_{2} \mathrm{O}_{2}$ and allowed 2 hours for disappearing colours. Then the sample was filtered with deionizing water and made volume up to $100 \mathrm{ml}$ in a volumetric flask. For heavy metal estimation it was taken $1 \mathrm{ml}$ digested sample, $10 \mathrm{ml} \mathrm{KI}(10 \%), 10 \mathrm{ml} \mathrm{HCL}$ and deionizing water to make $100 \mathrm{ml}$ volume in a standard flask and allowed 2 hours for taking reading by Atomic Absorption Spectrophotometer (AAS) (Model: Thermo Scientific-s-series AA Spectrometer, USA for Pb \& Cr; and Agilent technologies 200 series AA; 240 FJ AA for As). However, the processed samples were analyzed at the laboratory of Soil Science Division, Bangladesh Agricultural Research Institute (BARI), Gazipur; Bangladesh using its own protocol following the methods developed by Tripathi et al. (2002) with little modifications.

\section{Results and Discussion}

The results of heavy metal content are shown in the tables below. Table 1 shows that all samples were positive for $\mathrm{Cr}$ content with varying level. Concentration of $\mathrm{Cr}$ in loose feed and protein concentrates were higher than in ready feed of layer and broiler. On the other hand, layer feed had lower $(1.98 \mathrm{ppm})$ concentration than that of broiler feed $(9.09 \mathrm{ppm})$. Higher concentration $(6.36 \mathrm{ppm})$ was found in the meat of spent hen than that of broiler $(1.02 \mathrm{ppm})$ and cockerels (trace).

Table 1. Chromium (Cr) content in different samples of feed, meat and eggs.

\begin{tabular}{|c|c|c|c|c|c|c|c|}
\hline \multirow{2}{*}{\multicolumn{2}{|c|}{ Type of sample }} & \multirow{3}{*}{$\begin{array}{l}\text { No. of } \\
\text { sample }\end{array}$} & \multirow{3}{*}{$\begin{array}{l}\text { "+ ve"/ } \\
\text { "- ve" } \\
+ \text { ve }\end{array}$} & \multicolumn{3}{|c|}{ Level of Content } & \multirow{3}{*}{$\begin{array}{l}\text { Maximum } \\
\text { Permitted Conc. (ppm) }\end{array}$} \\
\hline & & & & Trace $(\%)$ & Max. (ppm) & Min (ppm) & \\
\hline \multirow[t]{2}{*}{ Layer feed } & Ready & & & 50 & 1.98 & 0.03 & \\
\hline & Loose & 20 & $+\mathrm{ve}$ & 55 & 358.05 & 0.69 & \\
\hline Broiler feed & Ready & 23 & $+\mathrm{ve}$ & 57 & 9.09 & 0.12 & $20-30 * *$ \\
\hline Protein concentrate & - & 9 & $+\mathrm{ve}$ & 11 & 1720 & 0.9 & $20-30 * *$ \\
\hline \multirow[t]{3}{*}{ Egg } & Albumen & 15 & $+\mathrm{ve}$ & 87 & 0.19 & 0.16 & $1 *$ \\
\hline & Yolk & 15 & $+\mathrm{ve}$ & 100 & - & - & \\
\hline & Whole egg & 12 & $+\mathrm{ve}$ & 100 & - & - & \\
\hline \multirow[t]{3}{*}{ Meat } & Broiler & 7 & $+\mathrm{ve}$ & 86 & 1.02 & - & $1 *$ \\
\hline & Cockerel & 3 & $+\mathrm{ve}$ & 100 & - & - & \\
\hline & Spent hen & 4 & $+\mathrm{ve}$ & 25 & 6.36 & 0.51 & \\
\hline
\end{tabular}

*Choi Ya Yin (2012); ** IAEA ( International Atomic Energy Authority) 
However, the findings agreed with the findings of (Sarker, 2014) who got higher Cr content in commercial poultry feed than the MPC level. The higher Cr content may be due to the using of tannery waste as a protein source in the feed. The Cr content in egg samples found were below the MPC level. The finding is in agreement with the finding of Basha et al. (2013), who found the Cr content in egg samples to be acceptable and within the permissible limits to human consumption in respect of nutritional and toxic levels as compared with the literature data reported from various parts of the world. The finding of the current study also comply with the finding of Alam et al. (2011) who got the permissible concentration of $\mathrm{Cr}$ for human consumption in both the meat and egg samples he studied. He also mentioned that a limited number of meat samples in his study area (Chittagong, Bangladesh) had higher $\mathrm{Cr}$ content than those studied abroad. This statement also partially got support with the finding of current study where, the meat of broiler and spent hen samples possess higher amount of Cr. It is worthwhile to point out that, Chromium, particularly $\mathrm{Cr}$ (III) plays an important role in the body function (metabolic functions, co-factor of insulin production etc.) in trace amount but it turns to be toxic when it exceeds the tolerance limit (Alam et al., 2011). However, a little increase in the concentration of $\mathrm{Cr}$ of broiler and spent hen meat samples also got support from the study of Abduljaleel et al. (2012), who reported higher $\mathrm{Cr}$ content of chicken tissue samples, but obviously lower than the permissible limits (ANZFA, 2001), $\mathrm{Cr}$ one of the heavy metals, essentially occurred in high levels in the tissues of birds because of its biological roles in the body, explained by the author. He also mentioned the consistency of his findings with that of the prior studies by Uluozlu et al. (2009) and Demirbas (1999).

Table 2 shows that all samples were positive for " $\mathrm{Pb}$ " content with varying level. The maximum " $\mathrm{Pb}$ " found in Protein concentrate while the minimum level found in broiler meat samples. However, the trace indicates below undetectable limit of Thermo AAS $(\mathrm{Pb}=<0.01 \mathrm{ppm}$ and $\mathrm{Cr}=<0.01 \mathrm{ppm})$. The findings also agreed with the findings of (Sarker, 2014) who got lower Pb content in commercial poultry feed than the MPC level. The higher $\mathrm{Pb}$ content in Protein concentrates might be due to using $\mathrm{Pb}$ treated leather shavings or any other protein waste as a protein source in the feed. The $\mathrm{Pb}$ content in meat and egg samples found in the current study as lower than the permissible limits also got support from the previous findings of Alam et al., 2011, Abduljaleel et al., 2012 and Basha et al. 2013, who got the $\mathrm{Pb}$ content in meat and egg samples below the permissible limits for human consumption. However, the current finding is disagreed with the finding of Islam et al., 2014, who got higher $\mathrm{Pb}$ content than the acceptable limits in egg samples collected from the Peshawar district of Pakistan. The difference might be attributed by the location variant which affected or contaminated by the environment or any other sources to poultry eggs, the author also mentioned and suggested further detailed investigation of water and feed used to feed those poultry birds.

Table 2. Lead $(\mathrm{Pb})$ content in different samples of feed, meat and eggs.

\begin{tabular}{|c|c|c|c|c|c|c|c|}
\hline \multirow{2}{*}{\multicolumn{2}{|c|}{ Type of sample }} & \multirow{4}{*}{$\begin{array}{l}\begin{array}{l}\text { No. of } \\
\text { sample }\end{array} \\
13\end{array}$} & \multirow{3}{*}{$\begin{array}{l}\text { "+ } \\
\text { ve"/ } \\
\text { "- ve" }\end{array}$} & \multirow{2}{*}{\multicolumn{3}{|c|}{ Level of Content }} & \multirow{3}{*}{$\begin{array}{l}\text { Maximum Permitted } \\
\text { Conc. }(p p m)\end{array}$} \\
\hline & & & & & & & \\
\hline \multirow{3}{*}{ Layer feed } & & & & & & & \\
\hline & Ready & & + ve & 93 & 0.75 & - & \multirow[t]{2}{*}{$10 * *$} \\
\hline & Loose & 20 & + ve & 95 & 0.86 & 0.69 & \\
\hline Broiler feed & Ready & 23 & + ve & 100 & - & - & $10 * *$ \\
\hline Protein Conc. & - & 9 & + ve & 78 & 30.27 & 3.34 & $10 * *$ \\
\hline \multirow[t]{3}{*}{ Egg } & Albumen & 15 & + ve & 100 & - & - & \multirow[t]{3}{*}{$6 *$} \\
\hline & Yolk & 15 & + ve & 100 & - & - & \\
\hline & Whole egg & 12 & + ve & 100 & - & - & \\
\hline \multirow[t]{3}{*}{ Meat } & Broiler & 7 & + ve & 71 & 0.51 & 0.09 & \multirow[t]{3}{*}{$6^{*}$} \\
\hline & Cockerel & 3 & + ve & 100 & - & - & \\
\hline & Spent hen & 4 & $+\mathrm{ve}$ & 100 & - & - & \\
\hline
\end{tabular}

*Choi Ya Yin (2012); ** IAEA (International Atomic Energy Authority)

Table 3 shows the arsenic level in various samples. All the tested samples were positive for As. The highest level found in broiler meat $(0.09 \mathrm{ppm})$ which exceeds the permitted level $(0.04 \mathrm{ppm})$ and the lowest concentration was in the spent hen (0.003). However, the findings agreed with the findings of (Sarker, 2014) who got higher "As" content in commercial poultry feed than the MPC level. The higher "As" content in broiler meat might be due to the exposure of "As" contaminated water to the birds. The finding also got support partially from Islam et al., 2014. 
Who found higher concentration of As in poultry egg samples and echoed as many researchers have reported that the increased content of the heavy metals is contributed the high intake of these elements by birds from feed and water.

Table 3. Arsenic (As) content in different samples of feed, meat and eggs.

\begin{tabular}{|c|c|c|c|c|c|}
\hline \multicolumn{2}{|c|}{ Type of sample } & $\begin{array}{l}\text { No. of } \\
\text { sample }\end{array}$ & $\begin{array}{l}\text { "+ ve"/ } \\
\text { "- ve" }\end{array}$ & $\begin{array}{l}\text { Level of Content } \\
\text { Max. (ppm) } \\
\end{array}$ & $\begin{array}{l}\text { Maximum Permitted Conc. } \\
(\mathrm{ppm})\end{array}$ \\
\hline \multirow{2}{*}{ Layer feed } & Ready & 13 & $+\mathrm{ve}$ & 0.08 & $1.4 * *$ \\
\hline & Loose & 20 & $+\mathrm{ve}$ & 0.07 & \\
\hline Broiler feed & Ready & 23 & $+\mathrm{ve}$ & 0.03 & $1.4 * *$ \\
\hline Protein Conc. & - & 9 & $+\mathrm{ve}$ & 0.04 & $1.4 * *$ \\
\hline \multirow[t]{3}{*}{ Egg } & Albumen & 15 & + ve & 0.01 & $0.04 *$ \\
\hline & Yolk & 15 & + ve & 0.01 & \\
\hline & Whole egg & 12 & $+v e$ & 0.004 & \\
\hline \multirow[t]{3}{*}{ Meat } & Broiler & 7 & + ve & 0.09 & $0.04 *$ \\
\hline & Cockerel & 3 & + ve & 0.02 & \\
\hline & Spent hen & 4 & + ve & 0.003 & \\
\hline
\end{tabular}

*Choi Ya Yin (2012); ** IAEA (International Atomic Energy Authority)

\section{Conclusions}

From the above findings it may be concluded that all the tested samples were positive for all the three heavy metals $(\mathrm{As}, \mathrm{Pb} \& \mathrm{Cr}$ ); but, the contents were traces in many cases. Thus, the levels were not at the harmful limits except some of the feed samples for $\mathrm{Cr} \& \mathrm{~Pb}$, broiler and spent hen meat for As content. Therefore, further thorough investigation is needed to provide the proper guidance for regulatory authority in the country for the sake of healthy nation especially free from heavy metal contamination.

\section{Acknowledgements}

We like to acknowledge the Soil Science Division, Bangladesh Agricultural Research Institute (BARI), Gazipur; Bangladesh for their sincere co-operation for analyzing the samples. We also show our gratitude to those Govt. and private company officers and poultry farmers who help to collect the samples.

\section{Conflict of interest}

None to declare.

\section{References}

Abduljaleel SA, M. Shuhaimi-othman and A Babji, 2012. Assessment of trace metals contents in chicken (Gallus gallus domesticus) and quail (Coturnix coturnix japonica) tissues from Selangor (Malaysia). Journal of Environmental Science and Technology, 5: 441-451.

Alam Z, Chowdhury, ZA Siddique, SMA Hossain, KA Islam, AA Ahsan, S Ahmed and MM Zaman, 2011. Determination of essential and toxic metals in meats, meat products and eggs by spectrophotometric method. Journal of the Bangladesh Chemical Society, 24: 165-172.

ANZFA, 2001. Australia New Zealand food authority. Wellington, New Zeland 6036.

Basha AM, N Yasovardhan, SV Satyanarayana, GVS Reddy and AV Kumar, 2013. Assessment of heavy metal content of hen eggs in the surroundings of uranium mining area, India. Annals. Food Science and Technology, 14: 344-349.

Demirbas A, 1999. Proximate and heavy metal composition in chicken meat and tissues. Food Chem., 67: 2731.

Hillerton JE, BI Halley, P Neaves and MD Rose, 1999. Detection of antimicrobial substances in individual cow and quarter milk samples using delvotest microbial inhibitor tests. J. Dairy Sci., 82: 704-711.

Hapke H J, 1996. Heavy metals transfer in the food chain to humans. Fertilizers and Environment, 66: 431-436

Iwegbue CMA, GE Nwajei and EH Iyoha, 2008. Heavy metal residues of chicken meat and gizzard and turkey meat consumed in southern Nigeria. Bulg. J. Vet. Med., 11: 275-280.

Jenseen HA, 1980. Chromatographic methods. J. of Chromatography, 30: 30-37. 
Mulder RWAW, 2011. Control of pathogenic micro-organisms in poultry production processing. Proceedings of the 7th International Poultry show and seminar, 25-27 March 2011, Dhaka, Bangladesh. Edited by: World's Poultry Science Association, Bangladesh Branch. pp. 37-43.

Sarker NR, 2014. SPGR Sub-Project completion Report on Coordinated project on contaminants and adulterants in food chain and their mitigation: BLRI component, Submitted to PIU-BARC complex, Farmgate, Dhaka1215.

Sarker NR, MK Alam, MN Munsi and R Khatun, 2011. Study on contaminants and adulterants in milk and meat in some selected locations. Coordinated project on contaminants and adulterants in food chain and their mitigation: BLRI component. Proceedings of Annual Research Review workshop, Bangladesh Livestock Research Institute, Savar, Dhaka. 2011. pp.151-159.

Uluozlu OD, M Tuzen, D Mendil and M Soylak, 2009. Assessment of trace element contents of chicken products from Turkey. J. Hazard. Mater., 163: 982-987.

Vasanthakumar P, D Chandrasekaran, MR Purushothaman, D Rajendran and C Kathirvealn, 2013. Incidence of adulteration of animal proteins with leather meal. Int. Livest. Res., 3: 139-140.

Zhuang, PH Zou and W Shu, 2009. Biotransfer of heavy metals along a soil-plant-insect-chicken food chain: field study. J. Envir. Sc. China, 21: 849-853. 